2012

\title{
The Case for Leverage-Based Corporate Human Rights Responsibility
}

Stepan Wood

Osgoode Hall Law School of York University, swood@osgoode.yorku.ca

Follow this and additional works at: http://digitalcommons.osgoode.yorku.ca/all_papers

\section{Repository Citation}

Wood, Stepan, "The Case for Leverage-Based Corporate Human Rights Responsibility" (2012). All Papers. Paper 2.

http://digitalcommons.osgoode.yorku.ca/all_papers/2

This Working Paper is brought to you for free and open access by the Research Papers, Working Papers, Conference Papers at Osgoode Digital

Commons. It has been accepted for inclusion in All Papers by an authorized administrator of Osgoode Digital Commons. 


\title{
The Case for Leverage-Based Corporate Human Rights Responsibility
}

\author{
Stepan Wood \\ Osgoode Hall Law School, York University, Toronto, Canada \\ 28 September, 2011 \\ Forthcoming: Business Ethics Quarterly 22(1): 63-98 (2012) \\ Special issue on Business and Human Rights \\ (guest editors Denis Arnold, Wes Cragg and Peter Muchlinski) \\ http://ssrn.com/abstract=1937895
}

\begin{abstract}
Should companies' human rights responsibilities arise, in part, from their "leverage"their ability to influence others' actions through their relationships? Special Representative John Ruggie rejected this proposition in the United Nations Framework for business and human rights. I argue that leverage is a source of responsibility where there is a morally significant connection between the company and a rights-holder or rights-violator, the company is able to make a contribution to ameliorating the situation, it can do so at modest cost, and the threat to human rights is substantial. In such circumstances companies have a responsibility to exercise leverage even though they did nothing to contribute to the situation. Such responsibility is qualified, not categorical; graduated, not binary; context-specific; practicable; consistent with the social role of business; and not merely a negative responsibility to avoid harm but a positive responsibility to do good.
\end{abstract}

\section{Keywords}

Corporate responsibility, business and human rights, leverage, sphere of influence, John Ruggie 


\section{INTRODUCTION}

In the field of business and human rights, should a company's "leverage” over other actors with whom it has a relationship - that is, its ability to influence their decisions or activities for better or worse-give rise to responsibility, rendering it answerable for its exercise or failure to exercise such leverage? I argue that the answer is a qualified yes: leverage is one factor giving rise to responsibility even where the company is not itself contributing adverse human rights impacts. The case for leverage-based responsibility has not been articulated clearly in the scholarly literature. Instead this issue tends to be subsumed in debates about "sphere of influence” (SOI) and complicity, with which it overlaps only partially. One of the few commentators to address the issue head-on is the Special Representative of the United Nations Secretary General on business and human rights, Professor John Ruggie (“SRSG”), who explicitly rejected leverage as a basis for the business responsibility to respect human rights (United Nations 2008b: 18, 2008a). In this article I attempt to supply the missing normative argument in favour leverage-based responsibility and in the process answer the SRSG's critique.

It is necessary first to distinguish three issues that are often obscured in debates about leverage and SOI: first, the relationship between companies' impacts on human rights and their leverage over other actors; second, the relationship between negative and positive forms of responsibility; and third, the relationship between companies' human rights obligations and their optional efforts to support human rights. I examine these distinctions in the first section. Next, I provide a concrete context for my argument by describing how the debate about leverage and SOI was brought into relief in the recent encounter between the SRSG's three-part "Protect, Respect and Remedy” framework (United Nations 2008b) and the International Organization for Standardization's ISO 26000 guide on social responsibility (International Organization for Standardization 2010).

I then turn to the normative case for leverage-based responsibility. I start by identifying some limitations of an impact-based conception of social responsibility. I then propose that leverage-based responsibility should arise when four criteria are satisfied: (a) there is a morally significant connection between the company and either the 
perpetrator of human rights abuse or the human rights-holder, (b) the company is able to make a difference to the state of affairs, (c) it can do so at an acceptable cost to itself, and (d) the actual or potential invasion of human rights at issue is sufficiently serious. I argue that such responsibility (e) is qualified rather than categorical, (f) is a matter of degree rather than a binary choice, (g) is context-specific, (h) can be both negative and positive in character, (i) satisfies the practicality criterion, and (j) is appropriate to the specialized social function of business organizations.

\section{VARIETIES OF RESPONSIBILITY}

Three interwoven distinctions are often obscured or conflated in the debate about corporate leverage and SOI: influence as “impact” versus influence as “leverage,” negative versus positive responsibility, and obligatory versus optional human rights practices (Wood 2011a, 2011b). To understand the debate it is necessary to tease apart these distinctions. First, as the SRSG points out, the SOI concept conflates two very different meanings of "influence":

One is “impact”, where the company's activities or relationships are causing human rights harm. The other is whatever "leverage” a company may have over actors that are causing harm or could prevent harm. (United Nations 2008a: 5)

These two forms of influence have different practical and moral implications, and correspond to two different conceptions of responsibility. Impact-based responsibility attaches to an organization's direct and indirect contributions to social or environmental impacts. Leverage-based responsibility, by contrast, arises from an organization's ability to influence the actions of other actors through its relationships, regardless of whether the impacts of those other actors' actions can be traced to the organization. The business responsibility to respect human rights, as defined by the SRSG, is primarily impactbased. The SRSG initially rejected leverage-based responsibility (United Nations 2008b: 18, 2008a), but as I will show, his final Guiding Principles on Business and Human Rights endorse a limited version of it (United Nations 2011b). 
The second distinction needing attention is that between negative and positive responsibility. I use these terms to refer, respectively, to a responsibility to "do no harm" and a responsibility to "do good" (Griffin 2004: 19; Moore 2009: 34). This is not the same as a responsibility not to act and a responsibility to act, as is often thought. The distinction between negative rights entailing negative obligations to refrain from certain actions, and positive rights entailing positive obligations to take action, is artificial and inconsistent with social reality. As Arnold points out, "it is not possible to protect a person from harm without taking proactive steps," for example by designing, establishing, staffing, financing and operating the necessary institutions. As a result, the notion of negative versus positive rights loses its meaning: "There are only rights and corresponding obligations, but the obligations that correspond to these rights are both negative and positive” (Arnold 2009: 65-66). The business responsibility to respect human rights, as articulated by the SRSG, is a negative responsibility to avoid causing or contributing to human rights violations, rather than a positive responsibility to fulfill or support the realization of human rights. That said, the SRSG recognizes that negative responsibilities may require an actor to take affirmative steps to discharge its responsibility (not least, by conducting human rights due diligence) and that consequently a company can fail to discharge its responsibility by both omission and action (United Nations 2008b: 17, 2011b: 14).

The intersection of these two distinctions generates four types of social responsibility:

1. Impact-based negative responsibility: Companies have the responsibility to avoid contributing to negative social or environmental impacts directly or through their relationships;

2. Leverage-based negative responsibility: Companies have the responsibility to use their leverage to prevent or reduce the negative social or environmental impacts of other actors with whom they have relationships regardless of whether the companies themselves have contributed or are contributing to such impacts; 
3. Impact-based positive responsibility: Companies have the responsibility to contribute to positive social or environmental impacts directly or through their relationships; and

4. Leverage-based positive responsibility: Companies have the responsibility to use their leverage to increase or maximize the positive social or environmental impacts of other actors with whom they have relationships. (Wood 2011a)

The SRSG's framework for business and human rights endorses impact-based negative responsibility, leaves a little room for leverage-based negative responsibility, and rejects both forms of positive responsibility. I will argue in favour of all four varieties of responsibility.

The third distinction at work in the debate about corporate leverage and spheres of influence is between companies’ inescapable human rights obligations and optional practices which organizations may choose or be encouraged to adopt. Some commentators, the SRSG included, suggest that exercising leverage to support or fulfill human rights is an optional matter, not an obligation (Sorell 2004: 140; United Nations 2010: 13, 2008a: 5). In this article I am concerned only with defining the boundaries of the obligations owed by business to society. Following Goodpaster, I define corporate responsibility as "the acknowledged or unacknowledged obligations that every company has as it pursues its economic objectives” (Goodpaster 2010: 126; Cragg 2010: 283-284). No one disagrees that organizations may as a discretionary matter, on a voluntary basis and subject to certain caveats, use their leverage to promote positive social or environmental outcomes, or prevent or mitigate negative outcomes. I will argue that in certain circumstances they have an obligation to do so.

\section{THE “SPHERE OF INFLUENCE” DEBATE}

\section{Emergence of the SOI Concept}

One of the abiding questions regarding corporate social responsibility is where to draw the boundaries of an organization's responsibility when other actors with whom it is connected engage in human rights abuses or other socially irresponsible conduct. In what 
circumstances and to what degree, for example, should an apparel company be responsible for violations of workers' rights in its suppliers' factories; should a mining company be responsible for illegal killings by security forces contracted to protect its assets and personnel; should a battery manufacturer be responsible for contamination caused by leaching of toxins when its products are disposed improperly; should a firearms manufacturer be responsible when police use its products to shoot at citizens assembled peacefully; should banks be responsible when the proponents of projects they finance displace indigenous people forcibly; or should makers of fuels, solvents or adhesives be responsible when children sniff their products to get high?

The concept of "sphere of influence" (SOI) was introduced into social responsibility discourse in 2000 by the United Nations Global Compact in an effort to answer this question. The Global Compact urges member companies to embrace, support and enact ten principles of socially responsible conduct "within their sphere of influence" (United Nations Global Compact Office (no date)). According to Professor Ruggie, the main drafter of the Global Compact before he became the SRSG, SOI can be a useful metaphor for thinking about a company's responsibilities beyond the workplace (United Nations 2008a: 6). The concept of a "sphere" reflects two core propositions: first, that organizations have the ability, within certain limits, to influence actions and outcomes outside their own organizational boundaries through their relationships with other actors, and secondly, that business firms and states perform distinct social functions in distinct social domains, giving rise to distinct roles and responsibilities (de Schutter 2006: 12).

The SOI is often depicted as a series of concentric circles with the organization's workplace at the centre, followed by its supply chain, marketplace, the communities in which it operates, and finally an outermost sphere of government and politics (United Nations 2008a: 4). This model assumes that a company's influence diminishes with distance from the centre of its sphere (United Nations 2008a: 4), an idea often operationalized in terms of "proximity":

The closer a company is to actual or potential victims of human rights abuses, the greater will be its control and the greater will be the expectation on the part of stakeholders that the company is expected to support and respect the human rights 
of proximate populations. Similarly, the closeness of a company's relationship with authorities or others that are abusing human rights may also determine the extent to which a company is expected by its stakeholders to respond to such abuse. (Business Leaders Initiative on Human Rights et al. (no date))

The draft United Nations Norms on the responsibilities of transnational corporations in relation to human rights employed the SOI concept in a literal sense to define corporate obligations: "Within their respective spheres of activity and influence, transnational corporations and other business enterprises have the obligation to promote, secure the fulfilment of, respect, ensure respect of and protect human rights" (United Nations 2003: Article A.1). The potential significance of this direct, obligatory application of the SOI concept was magnified by two facts: first, the Norms defined corporate responsibility as including positive obligations to protect, promote and secure the fulfilment of human rights, not just a negative responsibility to avoid violating them; and second, the corporate human rights obligations identified by the Norms were of the same general type and scope as those of States, leaving the concept of "spheres of activity and influence" to do most of the work to distinguish between them.

In 2004 the UN Human Rights Commission welcomed the Draft Norms and asked the Office of the High Commissioner to prepare a report on existing standards related to business and human rights that would identify outstanding issues and make recommendations for strengthening such standards and their implementation. The resulting 2005 report endorsed the use of the sphere of influence concept to define the boundaries of business responsibility for human rights. Noting that the concept sets limits on responsibility according to a business entity's power to act, it concluded that it could "help clarify the boundaries of responsibilities of business entities in relation to other entities in the supply chain...by guiding an assessment of the degree of influence that one company exerts over a partner in its contractual relationship—and therefore the extent to which it is responsible for the acts or omissions of a subsidiary or a partner down the supply chain” (United Nations 2005a: 14). The High Commissioner also concluded that the SOI concept should help draw boundaries between the responsibilities of States and businesses, and to ensure that small businesses "are not forced to undertake over- 
burdensome human rights responsibilities, but only responsibilities towards people within their limited sphere of influence” (United Nations 2005a: 14). The report recommended that the Commission consider and further develop the SOI concept.

The Commission welcomed the High Commissioner's report and requested that the UN Secretary-General appoint a Special Representative on business and human rights for an initial period of two years, with a mandate to "identify and clarify standards of corporate responsibility and accountability for transnational corporations and other business enterprises with regard to human rights” (United Nations 2005b: para. 1(a)). One of the SRSG's tasks would be to clarify the implications of the concept of sphere of influence (ibid., para. 1(c)).

\section{The SRSG's Rejection of SOI}

In his early research, the SRSG found that many companies' human rights policies and practices mirrored the Global Compact's sphere of influence model (United Nations 2007: 21), and that its assumption of responsibility declining gradually as one moves outward from the workplace "appears to reflect an emerging consensus view among leading companies" (United Nations 2006: 10). He nevertheless rejected the use of SOI to define the scope of the business responsibility for human rights (United Nations 2008a: 6; see also Ruggie 2007: 825-826; 2008: 202-203).

The SRSG argued that while the SOI concept may have sufficed when the Global Compact was first introduced, companies now needed a clearer and more precise guide to their responsibilities, especially after SOI was incorporated in the draft UN Norms (United Nations 2008a: 5). According to the SRSG, the SOI concept's conflation of “influence as impact” with "influence as leverage” was problematic because imposing responsibility whenever a company has leverage would require assuming, inappropriately, that “can implies ought” (United Nations 2008a: 5). The SRSG concluded, to the contrary, that "companies cannot be held responsible for the human rights impacts of every entity over which they may have some leverage, because this would include cases in which they are not contributing to, nor are a causal agent of the harm in question” (United Nations 2008a: 5). Moreover, requiring companies to act 
wherever they have leverage would invite political interference and strategic manipulation (United Nations 2008a: 5-6, 2008b: 20; Ruggie 2007: 826).

The SRSG also took issue with the tendency to operationalize SOI in terms of "proximity", noting that its most intuitive meaning, geographic, is often misleading since companies' activities can have effects very far away (United Nations 2008a: 6). The SRSG concluded that "it is not proximity that determines whether or not a human rights impact falls within the responsibility to respect, but rather the company's web of activities and relationships” (United Nations 2008a: 6). In short,

the scope of due diligence to meet the corporate responsibility to respect human rights is not a fixed sphere, nor is it based on influence. Rather, it depends on the potential and actual human rights impacts resulting from a company's business activities and the relationships connected to those activities. (United Nations 2008a: 8).

The SRSG also rejected the Norms' contention that corporations have positive human rights duties, defining the business responsibility to respect human rights in negative terms of avoiding harm (United Nations 2008b). The Human Rights Council welcomed the SRSG's reports and extended his mandate for a further three years to elaborate and operationalize the framework (United Nations 2008c). As a result of this endorsement, the SRSG's three-part Protect, Respect and Remedy framework is widely referred to as the "UN framework".

In short, according to the SRSG, the UN Norms, positive responsibility, sphere of influence and leverage were "out" as bases for defining business human rights responsibilities, while impacts and negative responsibility were "in". This did not mean, however, that leverage was irrelevant. While rejecting leverage as a basis for defining the scope of responsibility, he emphasized that responsibility arises not only from the impacts of a company's own decisions and activities, but also from the impacts generated through its relationships (United Nations 2010: 13). The SRSG thus contemplated responsibility arising in situations where the company itself was not contributing to negative impacts, but its relationships were. Responsibility in such circumstances would 
have to attach to the company's ability to influence other actors' contributions to negative impacts through its relationships rather than to its own contribution to such impacts, since such contribution is absent. This opens the door to a leverage-based conception of responsibility.

\section{SOI and the drafting of ISO 26000}

The SRSG's scepticism and the apparent demise of the draft UN Norms notwithstanding, the SOI approach remained very much alive in international CSR discourse and practice. In early 2005 the International Organization for Standardization (ISO) began to work on a guide on social responsibility, to be known as ISO 26000. ISO, a federation of the national standards bodies of approximately 160 countries, is the leading source of voluntary consensus standards for business (Murphy and Yates 2009). The guide was developed by the ISO Working Group on Social Responsibility (WGSR), a multistakeholder body made up, ultimately, of 450 representatives of business, labour, government, NGOs and other interests from 99 ISO member countries and 42 international organizations (International Organization for Standardization n.d.). Notably, no major international human rights organizations participated directly in the negotiations.

Sphere of influence featured prominently in the draft guide from the start, drawing on the Global Compact, the draft UN Norms and other sources. After several rounds of drafting, a near-final version known as a Draft International Standard (DIS) was circulated for ballot in 2009, more than a year after the SRSG published his views on sphere of influence and "leverage” (International Organization for Standardization 2009). The DIS continued to give the SOI concept a central role. In several passages it stated that leverage over other actors can give rise to responsibility, and that generally, the greater an organization's leverage, the greater its responsibility to exercise it (ibid., clauses 5.2.3, 7.3.2, 6.4.3.2, 6.3.10.12, 16.15).

These passages did not escape the SRSG's attention. In November, 2009, he sent a letter to the WGSR expressing concern about the DIS's treatment of leverage and sphere of influence (United Nations 2009). While acknowledging that the use of the sphere of influence concept in the human rights portion of ISO 26000 (clause 6.3) was 
broadly consistent with the UN Framework, he cautioned that its use in the rest of the document was not, and that this would send confusing messages to companies and stakeholders (United Nations 2009: 2). He reiterated his previously published concerns about leverage and sphere of influence (summarized above), and urged the working group to bring the Guide into closer alignment with the UN Framework.

The WGSR leadership took the SRSG's advice, substantially rewriting the definition of sphere of influence and the main clauses elaborating upon the concept in consultation with the SRSG's team. Many references to responsibility arising from and increasing with the ability to influence other actors' decisions and activities were removed, and replaced with a stronger emphasis on influence as "impact”. The changes were endorsed by the WGSR at its last meeting in Copenhagen in 2010, and later that year the final version of ISO 26000 was approved by a large majority of ISO member bodies and published (International Organization for Standardization 2010).

\section{The final version of ISO 26000}

Despite these last minute changes, influence and leverage continue to feature prominently in the published version of ISO 26000. The term "sphere of influence" appears 34 times in the guide and is integral to its definition of and approach to social responsibility (Wood 2011a, 2011b). ISO 26000 describes the relationship between impacts, leverage and responsibility as follows:

An organization does not always have a responsibility to exercise influence purely because it has the ability to do so. For instance, it cannot be held responsible for the impacts of other organizations over which it may have some influence if the impact is not a result of its decisions and activities. However, there will be situations where an organization will have a responsibility to exercise influence. These situations are determined by the extent to which an organization's relationship is contributing to negative impacts. (International Organization for Standardization 2010: clause 5.2.3) 
Emphasizing that organizations have a choice about the kinds of relationships they enter, the Guide warns that "There will be situations where an organization has the responsibility to be alert to the impacts created by the decisions and activities of other organizations and to take steps to avoid or to mitigate the negative impacts connected to its relationship with such organizations” (ibid.). Where organizations are not causing or contributing to human rights violations or other negative impacts directly or through their relationships, ISO 26000 notes that exercising influence to minimize negative impacts or enhance positive impacts is an optional opportunity, not a responsibility, and warns that exercising leverage can also have negative or unintended consequences (ibid., clauses 5.2.3, 6.3.2.2, 6.3.7.2, 7.3.2). In these respects ISO 26000 is aligned with the UN framework.

Other parts of ISO 26000, however, suggest that business responsibility is not just negative but also positive, contrary to the SRSG's formulation. The clause on general principles of social responsibility calls upon organizations, for example, to "respect and, where possible, promote" fundamental human rights (ibid., clause 4.1). Even the human rights clause urges organizations (among other things) to contribute to promoting and defending the overall fulfilment of human rights; promote gender equality; contribute to disabled people's enjoyment of dignity, autonomy and full participation in society; promote respect for the rights of migrant workers; and make efforts to advance vulnerable groups and eliminate child labour (ibid., clause 6.3.4.2, 6.3.7.2, 6.3.10.3).

ISO 26000 recognizes that fulfillment of such positive responsibilities will often require organizations to exercise leverage over other actors. The clause on fair operating practices urges organizations to use their relationships with other organizations to promote the adoption of social responsibility throughout their sphere of influence, encourage the development of public policies that benefit society at large, and raise the awareness of organizations with which they have relationships about principles and issues of social responsibility (ibid., clauses 6.6.1.2, 6.6.4 and 6.6.6). A passage on labour practices even asserts that "a high level of influence is likely to correspond to a high level of responsibility to exercise that influence" (clause 6.4.3.2).

Other passages of ISO 26000 suggest that in some circumstances an organization may have a responsibility to contribute to solving problems caused by others. For 
example, it urges organizations to take action to reduce and minimize pollution, prevent the use of certain toxic chemicals, and reduce greenhouse gas emissions by organizations within their sphere of influence (ibid., clauses 6.5.3.2, 6.5.5.2.1). Finally, an organization may have a responsibility to refrain from exercising its leverage in particular ways, regardless of whether such exercise would have any impact. Thus organizations should not engage in misinformation, intimidation, threats, efforts to control politicians, or other activity that can undermine the public political process, regardless of whether such nefarious activity actually bears fruit (ibid., clause 6.6.4). Similarly it is irresponsible to offer bribes or engage in other corrupt practices regardless of whether such bribes are accepted or such illicit efforts at influencing others' decisions and activities succeed (ibid., clause 6.6.3).

In short, ISO 26000 contains a mix of negative, positive, impact-based and leverage-based responsibility, although the passages on human rights tend to emphasize the negative, impact-based variety (Wood 2011a). In this respect it is more like the UN Global Compact, which exhorts companies to "embrace, support and enact” the ten principles within their spheres of influence, than the UN Framework, which defines the business responsibility for human rights as negative and based on contribution to impacts.

\section{Influence and Leverage in the SRSG's Guiding Principles}

In March, 2011, the SRSG submitted his final report to the UN Human Rights Council (United Nations 2011b). The report proposes Guiding Principles for implementing the UN Framework. What is most interesting about the Guiding Principles for present purposes is their acknowledgement that a company may be responsible for human rights violations to which it has not contributed:

The responsibility to respect human rights requires that business enterprises: ... Seek to prevent or mitigate adverse human rights impacts that are directly linked to their operations, products or services by their business relationships, even if they have not contributed to those impacts. (Ibid., 14, emphasis added) 
The operational guidance provided by the Principles distinguishes between three scenarios: where a business enterprise causes or may cause an adverse human rights impact, where it contributes or may contribute to an adverse human rights impact, and where it "has not contributed to an adverse human rights impact, but that impact is nevertheless directly linked to its operations, products or services by its business relationship” (ibid., 18). In other words, in the Guiding Principles a company's responsibility is not defined solely by its own contribution to impacts. Companies have a responsibility to prevent or mitigate negative human rights impacts to which they have not contributed, if these impacts are "directly linked" to the company via its business relationships. In such circumstances responsibility must attach to the company's ability to influence other actors through its relationships, since the company is not making any contribution to negative impacts. In this way, the Guiding Principles embrace a modest version of leverage-based responsibility.

The Human Rights Council endorsed the Guiding Principles enthusiastically in a June, 2011 resolution co-sponsored by several countries and supported almost unanimously by Council members (United Nations 2011a). With the Special Representative's work done, the Council's focus will turn now to promoting the effective and comprehensive dissemination and implementation of the UN Framework and Guiding Principles. Elaborating the circumstances in which the link between a company and a negative human rights impact is sufficiently "direct" to give rise to responsibility even where the company has not contributed to the impact will be one of the issues requiring attention as this work proceeds.

\section{THE CASE FOR LEVERAGE-BASED RESPONSIBILITY}

Insofar as the SRSG's Guiding Principles move toward accepting leverage-based responsibility, they make a step in the right direction. They do not go far enough, however. A comprehensive leverage-based conception of responsibility is needed. I make three assumptions for purposes of this argument. The first is that business organizations bear responsibilities to society other than to maximize returns to their shareholders. While this assumption still has its critics, it is shared widely by the UN 
framework, ISO 26000 and many commentators, and I do not intend to question it here. The second assumption is that the moral case of the individual can be projected onto the organization for purposes of social responsibility. Such projection raises difficult issues but is sufficiently accepted in the social responsibility and business ethics literature that it provides a workable starting point, provided that certain morally relevant differences between organizations and individuals are borne in mind (Archard 2004: 55; Palmer 2004: 69; Voiculescu 2007: 412-418; Goodpaster 2010: 131).

My third assumption is that responsibility is individual rather than collectivethat is (keeping in mind my second assumption, above), it attaches to individual organizations rather than to groups of organizations whose actions collectively advance or infringe human rights or environmental integrity. Many commentators, the SRSG included (Ruggie 2007: 839), have noted the inadequacy of individualist accounts of responsibility in view of the often collective, networked character of human rights violations and other social evils (e.g. Kutz 2000; Voiculescu 2007; Weissbrodt 2008: 387; Wettstein 2010c; Young 2004). A collective theory of responsibility may ultimately be necessary to respond to this reality. In this article, however, I confine myself to exploring how we might address this challenge within an individualist conception of responsibility.

Finally, my defence of leverage-based responsibility should not be mistaken for a defence of the SOI approach. Like the SRSG, I consider the spatial metaphor of nested spheres radiating out from the workplace inapt and potentially misleading, and its tendency to conflate "influence as impact" with "influence as leverage" unhelpful. It should be replaced with a metaphor that is truer to social reality, such as the "web of activities and relationships” suggested by the SRSG himself.

\section{The limitations of impact-based responsibility}

The moral case for impact-based responsibility is strong. It is based on the moral intuition that we are responsible for the results of our own actions, barring exceptional situations such as incapacity or involuntariness (Moore 2009: 30-33 and 95; Hart and Honoré 1985: 63-65). Our degree of culpability (e.g. intending or recklessly risking a result versus bringing about unforeseen results by mistake) and of contribution (e.g. being 
a necessary and sufficient cause versus a substantial factor, or making a causal contribution versus non-causally occasioning an outcome) may affect the degree of blameworthiness or praiseworthiness attached to our conduct, but the "ethical bottomline,” as Wiggen and Bomann-Larsen put it, "is simple: you are responsible for the actual harm you cause or contribute to, no matter where you operate” (Wiggen and BomannLarsen 2004: 7).

An impact-based account of responsibility must overcome two challenges: unintended side effects and interactive social outcomes. The first challenge arises where an actor's decisions and activities bring about negative results that the actor did not intend. The principle of double effect offers one response to this challenge. Under this venerable doctrine, actors have a responsibility to prevent unintended but foreseeable side-effects and take measures to minimize the harm caused (Bomann-Larsen 2004: 91). Action that produces harmful side-effects is nevertheless permissible provided that the primary goal of the action is legitimate, the side-effects are neither part of the end sought by the actor nor means to this end, the actor aims to prevent or minimize them, and no alternative courses of action are available that would result in fewer or no side-effects (Wiggen and Bomann-Larsen 2004: 5). The issue of unintended side-effects, however important for business ethics, is not relevant to this article because regardless of how one treats them, both the problem and its solution fall clearly within the domain of impactbased responsibility and no question of leverage-based responsibility arises (Wiggen and Bomann-Larsen 2004: 10-11).

The second challenge facing impact-based responsibility is the prevalence of interactive social outcomes. Many social and environmental conditions are the products of complex social interactions in which chains of causation are long and convoluted, outcomes are not within the control of individual actors, and contributions are difficult or impossible to tease apart. This does not fit well with a traditional conception of moral responsibility according to which "one can only be held responsible for that over which one has control” (Beckmann and Pies 2008: 91). This criterion of individual outcome control is an instantiation of the maxim "ought implies can": "you can only have a moral obligation if it is causally possible for you to carry it out" (Banerjee et al. 2006: 313). If we were to apply this criterion rigidly to require individual control of social outcomes as 
a condition for moral responsibility, no one would be responsible for many outcomes in today’s complex world.

One response to this problem is to relax the causation requirement. This can be done in two ways. First, the relation between the agent's conduct and the outcome might be diluted from "but-for" causation to "substantial factor" or some otherwise lowered threshold of causal contribution (Moore 2009: 105, 300). Secondly, contribution can be defined in non-causal terms. Moral responsibility can and often does arise in the absence of causal contribution. Examples of non-causal contributions to undesirable outcomes that may in the right circumstances give rise to moral responsibility include omissions or neglect (in which the operative relationship is one of counterfactual dependence rather than causation), culpable imposition of risk (in which the operative relationship is probabilistic dependence rather than causation), and culpable but unsuccessful efforts to do harm (Hart and Honoré 1985: xlv-xlvi, 63-65; Moore 2009: 54-55, 307-311, 314-317, 444-451; Soule et al. 2009: 541-543). To be clear, responsibility for omissions is noncausal: an omission does not cause the outcome it failed to prevent (Moore 2009: 54-55, 444-451).

The UN framework reflects both of these general strategies: it rejects a narrow focus on causation in favour of “causing or contributing” (United Nations 2008a: 6, 2011b), and it embraces both causal and non-causal forms of contribution. To be precise, it emphasizes causal contributions, in the form of the direct and indirect impacts of companies’ own decisions and operations (e.g., United Nations 2008b: 20). But it contemplates responsibility for both actions and omissions, and refers to such non-causal contributions as failing to conduct human rights impact assessments, failing to integrate human rights policies throughout a company, failing to monitor human rights performance, and silently encouraging or legitimizing human rights abuses (United Nations 2008a: 12, 2008b: 18-19, 21, 2010: 17, 2011b: 14). The Framework also sometimes uses the language of risk, which appears to imply a non-causal theory of responsibility (United Nations 2011b: 16-17).

Relaxing the causation requirement has the advantages of recognizing that causation is scalar, a matter of continuous variation (Moore 2009: 300), and that noncausal contributions can be morally relevant. It allows responsibility to be graduated to 
reflect different kinds and degrees of contribution, causal and non-causal. It does not, however, allow responsibility to be imposed in cases where it is impossible to determine individual contributions. Under this approach, if no contribution can be established, there is no responsibility.

Some might say that this is as it should be: no one should be held responsible for a state of affairs to which he or she did not contribute, causally or otherwise. But individual responsibility can arise in the absence of contribution to outcomes, causal or otherwise. Leading examples are role-based responsibilities such as that of a principal for harm caused by an agent, a parent for the actions of a minor, an occupier of property for injuries sustained by visitors, or a captain for the safety of a ship (Hart 1967, 2008; Gibson 2007: 99-100). Another is the responsibility to come to the aid of someone in peril given the right circumstances, an issue to which I will return.

A second response to the problem of interactive social outcomes, which often accompanies the first, is to characterize responsibility as qualified rather than categorical. Faced with the lack of individual outcome control, an actor's responsibility should be defined in terms of what he or she can control—making an effort—rather than what he or she cannot—achieving a particular result. In such a scenario, "even if a company does not have a categorical responsibility, a responsibility to resolve the moral challenge on its own, it can still have a qualified responsibility to make an effort—or to participate in the efforts of others in seeking a collaborative resolution” (Goodpaster 2010: 147). This satisfies the "ought implies can" maxim by defining the moral responsibility in terms of actions a firm can achieve by itself. Qualified responsibility is justified in the complex arena of social responsibility where agency is often diffuse and interdependent, and causal pathways hard to trace.

A third response is to make actors responsible for the institutional order in which interactions occur, rather than for specific interaction outcomes. In this approach, individual actors are responsible for contributing to the creation of the institutional order within which interaction occurs and for participating in a discourse aimed at identifying shared interests (Beckmann and Pies 2008; Pies et al. 2009; Ulrich 2008). Social interaction outcomes remain no one's responsibility, except in the rare cases where individual outcome control exists. This approach is unsatisfactory insofar as it deflects 
attention from where it ought to be, on responsibility for the actual outcomes of social interaction.

In conclusion, impact-based responsibility works where a causal connection can be established between an agent's actions and the effects felt by others. It applies, for example, where a company fires employees it suspects of agitating in favour of unionization. In this situation the causal impact of the company's action on the employees' rights is direct and clear. It also applies where a company insists on keeping the prices paid to its suppliers as low as possible, and this insistence contributes to a supplier's decision to require its employees to work uncompensated overtime, in an effort to cut its costs. In this situation the first company's action has an indirect impact, as one causal factor (possibly among many) contributing to the second company's decision. So long as the first company's contribution rises above some de minimus threshold, the company will bear responsibility for the harm commensurate with its degree of contribution and culpability. Impact-based responsibility can also apply to cases of noncausal contribution such as omissions and culpable creation of risk, by broadening what we mean by “contribution”.

Even with this expansion, a wide variety of situations where harm is being suffered, or good could be done, escape the application of impact-based responsibility because it is impossible to determine individual contributions to outcomes. The only

answer impact-based responsibility offers in these situations is that no one is responsible. To say that this is justified because contribution is a prerequisite for responsibility fails to recognize that responsibility can and does arise in the absence not just of causal contribution, but of contribution of any kind. Such situations call for finer-grained moral judgments. Some actors are more closely connected to such situations than others, some act in more blameworthy ways than others, and some have more opportunities to act than others. We need a theory of responsibility that allows us to make these kinds of distinctions. Leverage-based responsibility is one such theory.

\section{Power and responsibility}

The kernel of a leverage-based approach is the proposition that, in some circumstances where a company is making no causal or other contribution to a state of affairs, it has a 
responsibility to exercise its leverage over actors with whom it has relationships in an effort to improve that state of affairs. Lack of contribution may not rule out a responsibility to contribute. The same idea can be expressed in terms of impact: even where a company is having no impact, it may have an obligation to try to have an impact by exercising its leverage over others. The question in such cases is not "are we contributing?” but “could we contribute?” If we are not part of the problem, should we nevertheless be part of the solution?

The case for leverage-based responsibility starts with the fact of the substantial power of business enterprises to influence social conditions, including the enjoyment of human rights (Sorell 2004: 138; Wiggen and Bomann-Larsen 2004; Moon et al. 2008). This power is widely believed to be increasing under contemporary conditions of globalization, while the capacity of governments to protect human rights is under strain (Cragg 2004, 2010; Scherer et al. 2009). In many cases corporations have substantial influence over people's material well-being; in some cases they exercise government-like functions, providing such public goods as education, security and health care; in rare cases they have the ability to determine life and death. Not only do they have substantial impacts on society and environment, they often have the leverage to make a difference, for better or worse, to problems not strictly of their own making:

The claim that businesses have obligations to protect and promote human rights is controversial, but the claim that they have opportunities to do so is not. ... Businesses, especially big businesses, are influential, and governments that rely on their investment for economic development, or even for corrupt personal enrichment, will not be unwilling to listen to what businesses have to say about a wide range of topics, including human rights. (Sorell 2004: 129)

What are the moral implications of this power? What is the relation between companies' size, resources and leverage, on one hand, and their human rights obligations, on the other? This is, as Sorell notes, "perhaps rhetorically and practically the hardest thing to get clear about when one discusses the human rights obligations of companies” (Sorell 2004: 138). At the highest level of generalization, we might assert that with 
corporate power comes responsibility (Windsor 2001; Wiggen and Bomann-Larsen 2004: 3; Scherer and Palazzo 2007; Kobrin 2009: 350). According to Cragg, "With the power of corporations to impact the enjoyment of human rights on the part of those affected by their operations comes the responsibility to protect and respect human rights in the exercise of that power” (Cragg 2010: 288).

Some commentators go farther, arguing not just that power must be exercised responsibly but that there may be a responsibility to exercise power. Campbell identifies companies' capacities, "that is, their ability and opportunity to make a difference to fundamental human interests within and beyond their own core sphere of activity,” as one factor defining their human rights responsibilities, and asserts that "concentrating on what it is that different sorts of organisation are capable of achieving gives us a fruitful basis for looking not only to where the duties correlative to human rights may fall, but what those duties may actually be” (Campbell 2004a: 15-16). Sorell argues that "when businesses have the opportunity to promote or protect human rights where they operate, they are often also obliged to do so” (Sorell 2004: 130). Griffin argues that “accidental facts such as being in a position to help can impose moral responsibilities - and nothing more special to the situation may bring the responsibility than that” (Griffin 2004: 39). Do these observations support the proposition that corporations must in some circumstances exercise their leverage over other actors in an effort to ameliorate situations to which they did not contribute?

Some proponents of the sphere of influence approach suggest a simple equation: leverage-understood in terms of a company’s size, scale of operations, profits, capacity, financial and human resources, strategic position in particular networks, privileged access to elites, etc.- - equals responsibility, and the more leverage, the more responsibility. And size matters: the larger the company, "the larger the sphere of influence is likely to be" (United Nations 2005a: 14). The main author of the UN Draft Norms put it this way:

the larger the resources of transnational and other businesses, the more opportunities they may have to assert influence. Accordingly, larger businesses, which generally engage in broader activities and enjoy more influence, have 
greater responsibility for promoting and protecting human rights. (Weissbrodt and Kruger 2003: 912)

Surely this is too simple. If this logic were taken literally it would mean that a large multinational company whose operations and value chain raise very few human rights issues would have greater responsibility than a small company operating in an industry and location with extremely high human rights risks, simply because of its greater resources. It would mean that a prosperous Canadian company with no operations, sources of supply, shareholders or consumers in Cambodia would have a responsibility to help improve the lot of Cambodian children, simply because it can. The SRSG's objection that this would turn the "ought implies can” principle on its head is well-founded (United Nations 2008b: 19-20; see also United Nations 2008a: 5). He also rejected this proposition because leverage-based responsibility might push companies into performing roles that should be played by governments:

[T]he proposition that corporate human rights responsibilities as a general rule should be determined by companies' capacity, whether absolute or relative to States, is troubling. On that premise, a large and profitable company operating in a small and poor country could soon find itself called upon to perform everexpanding social and even governance functions - lacking democratic legitimacy, diminishing the State's incentive to build sustainable capacity and undermining the company’s own economic role and possibly its commercial viability. Indeed, the proposition invites undesirable strategic gaming in any kind of country context. (United Nations 2010: 13-14)

The danger of such strategic manipulation may be overstated (Wood 2011a: 19), but the underlying point is sound: anchoring responsibility in leverage alone is highly problematic. “Can” does not imply “ought”.

Sorell gives three convincing reasons why wealth and power are not, on their own, sources of responsibility. Firstly, a company need not be rich and powerful to discharge many human rights obligations (Sorell 2004: 139). Secondly, the risk of 
violating human rights and the difficulty of promoting or protecting them vary independently of companies' wealth and power:

Undifferentiated talk of business obligations to promote human rights, and images of businesses with no specific location in the world but bestriding the world, ignore the greater foreseeable risks of human rights violations that attend some places and some forms of business and the greater obligations of companies in those businesses and those places to attend to human rights problems. (ibid.)

Thirdly, if companies' human rights obligations are tied to their economic fortunes, a small business with a razor-thin profit margin might blamelessly neglect worker safety or suppress unionization, while a huge company that falls on hard times might lose its human rights obligations along with its wealth and power (ibid.). On the contrary, Sorell argues, "a company that loses its wealth and power retains its obligations but may become less and less able to discharge them" (ibid.).

As a result, Sorell and the SRSG suggest that wealth, power and other indicia of leverage are relevant as means of discharging social responsibilities, not as sources of responsibility (Sorell 2004: 139; United Nations 2011b: 14, 16, 18-19). I would not go this far. Leverage can be a source of responsibility, provided other factors are present. The leading example is the moral duty to come to the aid of those in distress (e.g., Griffin 2004: 39; Sorell 2004: 130-135; Moore 2009: 37).

\section{Good Samaritans}

The moral duty to come to the rescue of people in distress is an example of leveragebased responsibility. In such cases, capacity to help is a prerequisite for responsibility, not simply a means of discharging it: someone who cannot swim is not under an obligation to save a drowning baby (Santoro 2010: 292). It is worth repeating Griffin's affirmation that being in a position to help, even if entirely accidental, can impose moral responsibilities (2004: 39). Harm and suffering generate objective reasons for everyone to cut them short (Sorell 2004: 135; Nagel 1986: 152-156). 
When will such reasons be sufficiently compelling to impose a moral obligation on particular actors (Moore 2009: 37)? Speaking generally, four criteria must be satisfied: urgency, ability, opportunity and affordability (Archard 2004; Griffin 2004; Schmidtz 2000; Sorell 2004; Moore 2009: 37). First, the situation must be urgent. Urgency is a function of the importance of the interest at stake (e.g., life, limb, or basic human rights) and the immediacy and severity of the threat to that interest. Secondly, the putative helper must have the ability to help the person in distress, that is, the requisite knowledge, resources or experience. Thirdly, the putative helper must have the opportunity to help, that is, must be in the right place at the right time to deliver the needed help. As Archard reminds us, there is a critical difference between ability and opportunity:

I am able to administer First Aid to the victims of a road traffic accident. I can do so because I have secured the appropriate qualification, have the First Aid kit, know what I am doing, and have past experience of providing such help. However I only have the opportunity to render such aid if I am there when a traffic accident has taken place and there is a victim to whom I can give First Aid. (Archard 2004: 58)

Some commentators add that the helper must be uniquely qualified to help-that is, there must be no one in a better position (Schmidtz 2000). Finally, the putative helper must be able to help at modest (some would say insignificant) cost, inconvenience or danger to himself or herself (Archard 2004: 35; Soule et al. 2009: 547-548).

The duty to rescue applies to anyone and everyone who satisfies these conditions, including total strangers who are in a position to help purely by accident-whether passers-by who come upon a child flailing in a pond, tourists who witness a road accident while driving through a foreign country, or patrons who watch passively as a rape is committed in a bar (Moore 2009: 304). Since it applies to total strangers, it is appropriate that the duty be restricted to situations of urgent threats to fundamental interests, where the cost of helping is relatively small. 
There is a good argument that this duty applies to companies (Dunfee 2006; Griffin 2004; Schmidtz 2000; Sorell 2004; Soule et al. 2009: 547-548). Sorell gives the example of a company learning that, on its doorstep, "people's lives are being threatened, or their labour or land seized at the whim of the local military” (Sorell 2004: 132). The urgency of the victims' needs and the relative scarcity of alternative help put "claims on the resources of the company, even if the company, like a passing tourist, is in no way responsible for the emergency” (ibid., 130). While the analogy between the individual bystander and the company is not perfect, the disanalogy adds force to the argument. Companies that invest directly in a country are more like permanent residents than tourists:

What goes on in the country has more to do with them than with people who are quickly passing through. The human rights abuses that companies confront do not crop up suddenly and unexpectedly, like the road accident: they often predate the entry of the company and are known in advance to be features of local life. Again, they are not features of life which, like the accident on the road, can pass unnoticed if one's eyes are averted at the right moment, or that can be kept at a distance by driving away. (Ibid.)

Sorell argues that companies "have obligations to help those whose lives or liberty are under serious threat in their vicinity, because some of these threats put people in urgent and undeniable need of help from anyone who can help, and companies in their vicinity sometimes can” (ibid., 133).

The SRSG neither explicitly endorses nor rejects a business responsibility to come to the aid of those in distress. He recognizes that in some circumstances, "such as natural disasters or public health emergencies, there may be compelling reasons for any social actor with capacity to contribute temporarily” (United Nations 2010: 14), but he does not develop this idea further in his reports. He does explore the implications of a company's presence in a place where human rights are being violated, but only in the context of defining the scope of complicity and due diligence. Firstly, he concludes that mere presence in a place where human rights violations are occurring does not usually by 
itself constitute complicity (United Nations 2008a: 12 \& 21, 2008b: 21). The question of whether presence "at the scene” makes one complicit in others' abuses is not, however, the same as whether it can give rise to an independent responsibility to come to the aid of those in distress. If nothing else, the shaky moral and metaphysical ground on which the entire edifice of accomplice liability stands (Moore 2009: ch. 13) should lead us to explore other avenues.

The second context in which the SRSG discusses doing business in the presence of human rights violations is in defining the scope of human rights due diligence. Assessing human rights challenges in the specific country contexts where business activities take place is a key element of due diligence (United Nations 2008a: 7, 2008b: 17, 2011b: 17). Operating in contexts where human rights abuses occur should raise "red flags” for companies to proceed with caution (United Nations 2008a: 21), but does not on its own violate the responsibility to respect. Again, the question of the scope of due diligence is not the same as that of the existence of a free-standing responsibility to come to the aid of those in distress. Due diligence is the standard against which fulfillment of the responsibility to respect human rights is measured. Defining its content does not tell us whether there may be other duties beside the responsibility to respect, or whether the responsibility to respect should be defined differently.

In conclusion, there are good arguments for the existence of a moral duty on corporations to aid the distressed when they find themselves in the position of capable bystanders, and nothing in the SRSG's reports precludes such a possibility.

\section{Beyond rescue}

Even if we accept the existence of a business duty to aid the distressed, it is simultaneously to narrow and too broad to support my argument for a general leveragebased responsibility. It is too narrow because it applies only in situations of immediate and serious threat to such fundamental human interests as life and liberty. Under this logic, leverage-based responsibility would be limited to emergency situations which we can only hope will be marginal and exceptional. It would not apply in mainstream, routine business conditions, except in contexts where abuse of fundamental rights is the norm. On the other hand, it is too broad insofar as it applies to anyone and everyone in a 
position to help, including total strangers with no connection to the case aside from their fortuitous presence at a given time and place. Restricting the duty to narrowly defined emergencies is justified in light of the potentially unlimited range of duty-bearers, and the potentially unlimited range of duty-bearers is justified by the urgency of the threats at issue. But there is a place for an intermediate form of leverage-based responsibility that is not restricted to dire threats to the most basic interests and does not extend potentially to everyone in the world.

Responsibilities are determined by other moral considerations than just urgency and ability to help. The most important for my purposes is the prior existence of a special relationship between the company, on one hand, and the human rights-holder or rightsviolator on the other. By narrowing the range of potential duty-bearers to those with such a relationship, we are justified in broadening the circumstances in which leverage-based responsibility will arise.

The SRSG himself points to this possibility. Recall that the Guiding Principles on Business and Human Rights recognize that business enterprises have a responsibility to "seek to prevent or mitigate adverse human rights impacts that are directly linked to their operations, products or services by their business relationships, even if they have not contributed to those impacts” (United Nations 2011b: 14, emphasis added) . In such cases the company should exercise any leverage it has to prevent or mitigate the adverse impact. If it lacks leverage it should explore ways to increase its leverage by, for example, offering capacity-building to the related entity or collaborating with other actors. If it lacks leverage and is unable to increase its leverage it should consider ending the relationship, taking into account the potential adverse human rights impacts of doing so, the importance of the relationship to the company and the severity of the abuse. "As long as the abuse continues and the enterprise remains in the relationship,” the Guidelines warn, "it should be able to demonstrate its own ongoing efforts to mitigate the impact and be prepared to accept any consequences - reputational, financial or legal - of the continuing connection” (United Nations 2011b: 19).

As I showed earlier, this is an example of leverage-based responsibility as I define the term, despite the SRSG's earlier rejection of leverage as a basis for determining the scope of corporate responsibility. Responsibility attaches to the company’s ability to 
influence other actors through its relationships, rather than to its contribution to negative impacts, since it is not making any such contribution. The key factor giving rise to responsibility in this situation is the “direct link” between the enterprise's operations, products or services, on one hand, and human rights impacts, on the other, via its business relationships. The Guiding Principles are silent on what constitutes a "direct link.” One of my goals in this article is to specify what kind of link should suffice to ground this form of responsibility, putting some flesh on the bones provided by the Guiding Principles. I consider this issue next.

\section{Criteria for leverage-based responsibility}

I argue that leverage-based responsibility arises when four criteria are satisfied: (a) there is a morally significant connection between the company and either the perpetrator of human rights abuse or the human rights-holder, (b) the company is able to make a difference to the state of affairs, (c) it can do so at an acceptable cost to itself, and (d) the actual or potential invasion of human rights at issue is substantial.

\section{(a) Morally significant connection}

The first criterion for the existence of a responsibility to exercise leverage is a morally significant connection between the company, on one hand, and the human rights holder or rights violator on the other. In the basic rescue cases the connection is provided by the urgency of the victim's plight and the rescuer's being in the right place at the right time with the right resources. This connection crystallizes only at the moment these factors coincide. Often, however, there is a pre-existing relationship between a company and either the rights-holder or the perpetrator of harm. This can provide the morally significant connection sufficient to generate a broader leverage-based responsibility. For individuals, such relationships may be constituted by love, affection, friendship, vulnerability, family, employment or business; or by shared experiences, places, values, beliefs, interests, etc. Although corporations are not capable of some of these connections they have myriad commercial, contractual, political, cultural and other links to a wide variety of actors. Like individuals, they can have "deep commitments to particular persons, causes, careers, and institutions” (Griffin 2004: 40). They may be tied 
by investments and commercial relations to a place where human rights abuses are taking place, and they may depend on the services or good will of those who are guilty of the abuses (Sorell 2004: 130). Some of these connections are created by choice, others arise involuntarily. Some are known to the parties, others are not.

These relationships generate moral responsibilities. The closer the relationship, the stronger the responsibility (Santoro 2010: 292). At the "closer" end of the spectrum are what Moore $(2009,58)$ refers to as "obligations to the near and dear". Applied to companies this would likely include employees, on-site contractors, consumers of goods and services, direct suppliers, and the communities in which companies operate (Goodpaster 2010: 134). If a company is blatantly and systematically polluting water supplies, exploiting workers or intimidating union organizers in a particular local community, other companies who are also established in that community have a stronger moral obligation to exercise their leverage to get it to desist than companies with no presence there, all else being equal. When public authorities interfere with employees' rights to assembly or expression or take away their land without due process, their employer has a stronger responsibility to intervene than does a stranger. Where security forces use a company's products to commit human rights violations, or where individuals use a company's products (e.g., cough syrups, adhesives, solvents or fuels) to get high, the maker of the product has a stronger responsibility to do something about it than does a company that does not make such products. A company with operations in a specific developing country, employing its inhabitants and contributing to its economy, has more of a responsibility for human rights in that country than it does in a country in which it does no business, and more responsibility than does a company that has no operations in that country (Archard 2004: 58).

Responsibility is not determined solely by the closeness of the relationship to the rights-holder or rights-infringer. The character of the interest at stake also matters. The closer the connection between the interest that is threatened and the company's activities, products or services, the stronger the responsibility. A company has a stronger responsibility to exercise leverage over public officials who interfere with its employees' rights of expression when the subject of such expression concerns the company itself or its economic sector, than when it concerns something completely unrelated to the 
company, its operations, activities, products, or services. This point can be understood in terms of relevance: the more relevant the interest at stake to the company's activities, products or services, the stronger the responsibility (Sorell 2004: 133).

I have identified two types of connections that can be morally significant: the company's relationship to the person(s) involved and the relevance of the interests at stake to the company's activities, products and services. Either can be sufficient on its own to generate leverage-based responsibility. If the relationship to the rights-holder or violator is close enough, responsibility will arise regardless of whether the interest at stake concerns the company's activities, products or services. This might be the case, for example, when public authorities or security contractors kill or menace a company's long-time employee for reasons unconnected to the company, such as the employee's alleged political activities; or when a company is so pivotal to a local economy that the taxes and royalties it pays provide a substantial portion of the government's revenue which is then used to repress civil rights. Obversely, if the connection between the interest at stake and the company’s activities, products or services is close enough, responsibility will arise even if the relationship between the company and the rightsholder or violator is weak (as, for example, in the case of the glue-sniffing addicts). Responsibility will be strongest where both types of connection are strong, and weak or non-existent where both are weak or absent.

So, for example, a Norwegian oil company with operations in Nigeria does not have a responsibility to protest a Nigerian court's sentencing of a young woman to death by stoning in a different state in which the company has no investments, operations, suppliers or consumers, provided it has no relationship with the case or parties and the case does not concern its activities or products, or those of the oil industry (BomannLarsen 2004: 95). Likewise, to cite Lord Macaulay’s famous example, “a surgeon need not take a train from Calcutta to Meerut in order to save someone not his patient, even though unless the doctor takes the train that person will die” (Moore 2009: 58-59).

The relationships and connections that form the basis for this form of responsibility are often multiple and interwoven. In any given human rights risk situation, a company might have relationships with workers, labour unions, contractors, suppliers, customers, subsidiaries, affiliates, consumers, local residents, security forces, 
national public authorities, local governments, competitors, industry associations, nongovernmental organizations and more; and the human rights risks at play might be relevant to one or more of the company's products, services, labour practices, or political activities. The metaphor of a "web of relationships," suggested by the SRSG, is apt for describing this interconnecting, networked reality. Even if no single strand in the web is strong enough on its own, responsibility will still arise if the company's relationships with rights-holders or violators and the relevance of the interests at stake to its activities, products or services, taken together, constitute a significant connection. The determination of a morally significant connection should be holistic, considering all the relevant strands in the company's web of relationships.

The general idea I am advancing here, that a company’s relationships provide the morally significant connection giving rise to responsibility, is reflected in the Guiding Principles. They state that responsibility arises where a business enterprise has not contributed to an adverse human rights impact, "but that impact is nevertheless directly linked to its operations, products or services by its business relationship with another entity” (United Nations 2011b: 18). “Business relationships” include “relationships with business partners, entities in its value chain, and any other non-State or State entity directly linked to its business operations, products or services” (ibid., 14). This is potentially too restrictive in two ways. First, there is no reason to think that morally significant connections will be restricted to "business" relationships, if this term is understood as excluding “political,” "social” or “cultural” relationships. ISO 26000 is on a better track insofar as it speaks of "political, contractual, economic or other relationships” (International Organization for Standardization 2010: clause 2.19). Secondly, the insistence on a “direct link” to the company’s operations, products or services is too restrictive if it excludes cases where the connection is mediated through more than one party (for example, via two or three tiers of suppliers). The SRSG's effort to delimit the connection is important, so that responsibility not be all-encompassing. But this connection can arise in two ways, as I have argued: either via the relationship between the company and the rights-holder or violator, or via the relevance of the interest at stake to the company's activities, products and services. The Guiding Principles’ “direct link” criterion appears to conflate these two kinds of connection, and potentially 
to draw the line around responsibility too close to the company, excluding some morally significant connections.

It would nevertheless be inappropriate to draw the line too far from a company. O’Neill (1985, 1996: 99) argues, for example, that a moral agent has obligations to everyone whose actions the agent presupposes in conducting his or her own activity. Thus "when I buy a sweatshirt or a pair of shoes, my action presupposes the actions of all the persons connected with the process that transforms raw materials into clothes and brings them to my local store” (Young 2004: 372). As Young acknowledges, this approach might be appropriate for a collective form of responsibility, but it is too broad to fix the responsibilities of individual actors (Young 2004). My approach reaches for middle ground, by focusing on the dual factors of a company's connection to the rightsholder or violator and the relevance of the interest at stake to the company's activities, products or services.

The existence of a morally significant connection also satisfies or partially substitutes for the opportunity criterion that usually applies in rescue cases. A special relationship to the rights-holder or violator or a strong link to the company's activities, products or services, or both, provides the company with the opportunity to act. It is what puts the company in "the right place at the right time" to exercise whatever leverage it has to ameliorate the situation.

To sum up this part, the existence of a morally significant connection between the company and the rights-holder or violator is a prerequisite for leverage-based responsibility. Such connection can be created by a pre-existing relationship between the company and the person(s) involved, or the relevance of the interest at stake to the company's activities, products or services. The stronger these connections, the stronger the company’s responsibility. As Arnold (2010: 387) points out, where special relationships exist in the global economy, rights-claims are binding on specific obligation bearers; and wherever corporations do business they are already in special relationships with a variety of stakeholders, such as workers, customers, and local communities. These special connections are the fulcrum of my argument for leverage-based responsibility. To paraphrase Griffin (2004: 40), unless one stresses these connections, my proposal that ability (ie., leverage) can determine where responsibility lies looks distinctly odd. 


\section{(b) Ability}

Campbell (2004a: 15) remarks that companies' ability "to make a difference to fundamental human interests within and beyond their own core sphere of activity" is an essential factor in determining their human rights duties. In line with this observation, the second criterion for leverage-based responsibility is the company's ability to make a difference by exercising influence over others with whom it has relationships. As with the first criterion, the strength of responsibility varies with this ability. The greater the actor's chance of being effective and the greater its capacity to absorb the cost of action, the stronger the correlative responsibility (Santoro 2010: 292).

As in the basic rescue case, ability is a prerequisite for responsibility, not simply a means of discharging it. Unlike in the basic rescue scenario, however, the required degree of ability is modest. In the basic rescue situation, a high degree of ability is usually required for a duty to arise. According to some commentators, the duty to rescue arises only if the putative rescuer is uniquely qualified to relieve the sufferer's plight and success is more or less assured within a limited time (Soule et al. 2009: 547-548). This high standard may be justified when imposing moral responsibilities on total strangers who are in a position to help purely by accident. When the range of duty-bearers is limited by the requirement of an independent, morally significant connection, a lower threshold is appropriate. It is also appropriate in light of the reality, discussed earlier, that the individual outcome control presumed by the higher threshold is rare in our complex contemporary world. The standard should therefore be that the company has the ability to make an appreciable contribution to ameliorating the situation over a foreseeable period by exercising leverage through its relationships, not that it has a high probability of solving the problem by itself in a short time.

Furthermore, the relevant question is whether the company has the ability to make a difference not just by itself but in combination with others. Moore (2009: 304) cites a case in which bar patrons passively watched a rape, concluding that the patrons "had the ability to prevent the rape and did not, and that is sufficient to ground their responsibility". Let us assume that no single patron could have stopped the rape alone. This does not mean that none of them had a responsibility to act. On the contrary, they 
had a responsibility to make an effort to get other patrons to act jointly to stop the rape. Their ability to make a difference together gave rise to a duty to use their leverage over others toward that end.

The relationships through which companies can exercise leverage are sometimes the same relationships that establish the morally significant connection to the rightsholder or the perpetrator of abuse, sometimes not. For example, a morally significant connection may be established by the company’s relationship to its workers or local community members, while leverage may be exercise through the company's relationship to public authorities, industry associations or competitors.

\section{(c) Affordability}

The third criterion is that the company can make its contribution to ameliorating the situation at an acceptable cost to itself. In the basic rescue scenario there is a duty to rescue only if the cost and inconvenience to the rescuer are insignificant or small (Dunfee 2006; Griffin 2004: 35, 39; Moore 2009: 37, 59; Schmidtz 2000). Soule et al. (2009: 548) insist that the cost must "not disrupt the business, significantly impact earnings, or compromise other moral obligations," concluding not surprisingly that the duty will arise rarely in a business context. As with the other criteria, however, it is appropriate to relax this criterion when the range of potential duty bearers is limited by the prior existence of a morally significant connection to the rights-bearer or rights-violator. Where there is a special relationship, we can reasonably expect the duty bearer to incur somewhat more cost, inconvenience and risk than we would expect of the total stranger. Moreover, the cost we can expect the company to absorb will increase both with the strength of its morally significant connection to the state of affairs and with its ability to make a difference (Santoro 2010: 292).

As with the first two criteria, determining affordability is more a question of identifying a continuum than drawing a sharp line. The basic rescue principle is at the low end of the continuum, with its insistence on little or no cost to the rescuer. At the other extreme is the proposition that the rescuer must incur any cost consistent with mere survival as an agent (Griffin 2004: 35). As Griffin argues, the former standard is too lax, the latter too demanding. In his view the answer to the question of what cost is 
acceptable "is inevitably rough, but it is along these lines: at a cost within the capacities of the sort of persons we should want there to be” (ibid.: 36). These sorts of personsincluding companies and their managers - would not be utterly impartial, rather they would be committed to specific goals, institutions, relationships, places and people, willing to sacrifice themselves but only up to a point. Their obligation to exercise leverage does not go on until the their marginal loss equals the marginal gain of those they are helping; on the contrary, they are allowed substantially to honour their own commitments and follow their own interests, and these permissions limit their obligations (ibid.: 40). Perhaps the most we can say is that companies have a responsibility to make reasonable efforts at modest risk or cost to themselves (Sorell 2004: 132, 135), and that the cost they are expected to incur will increase with the strength of their morally significant connection to the state of affairs in question.

\section{(d) Urgency}

The final criterion for the existence of leverage-based responsibility is a substantial threat to or infringement of a human right. Once again, given the requirement of an independent morally significant connection to the rights-holder or rights-infringer, we are justified in relaxing the urgency criterion relative to that which would apply in a basic rescue scenario. Instead of an immediate threat to fundamental rights to life, limb, liberty or basic subsistence- - a threat that generates objective reasons for anyone who can to help the affected people-it is sufficient that there be a substantial threat to or interference with any human right. An immediate threat to a fundamental human interest is not a minimum threshold for leverage-based responsibility to arise, but a factor enhancing the strength of the responsibility. The more fundamental the interest at stake and the more severe the harm to that interest, the stronger the responsibility.

\section{Characteristics of leverage-based responsibility}

Four implications follow from my argument: that leverage-based responsibility is qualified, not cagetorical; graduated rather than binary; context-specific; and both negative and positive in character. Moreover, it is practicable and appropriate to the specialized social function of business. 
(e) Leverage-based responsibility is qualified, not categorical

One implication of my analysis is that leverage-based responsibility is qualified. It is a responsibility to make a reasonable effort to influence the behaviour of relevant others through relationships, rather than to achieve defined social interaction outcomes. As Goodpaster (2010: 147) argues, “even if a company does not have a categorical responsibility, a responsibility to resolve the moral challenge on its own, it can still have a qualified responsibility to make an effort-or to participate in the efforts of others in seeking a collaborative resolution”. This follows from the lack of individual outcome control in contemporary social interaction and is consistent with the "ought implies can" maxim, which demands that responsibilities be defined in terms of results that are within the capacity of moral agents to achieve.

The Guiding Principles reflect this differentiation. Impact-based responsibility is defined in terms of expected outcomes, while leverage-based responsibility is defined in terms of efforts. Companies have a responsibility to avoid causing or contributing to adverse human rights impacts (impact-based responsibility), but where they are not contributing to impacts, their responsibility is limited to seeking to prevent or mitigate adverse impacts that are directly linked to their operations, products or services (leverage-based responsibility) (United Nations 2011b: 14).

\section{(f) Leverage-based responsibility is graduated, not binary}

A second implication is that leverage-based responsibility is a matter of degree, not an “on/off” choice. The strength of responsibility varies positively with the strength of the company's morally significant connection to the state of affairs in question, its leverage over other actors, and the seriousness of the threat to or infringement of human rights; and negatively with the cost of exercising leverage. The threshold between no responsibility and responsibility is necessarily broad and indistinct. It is defined not by a bright line but by a combination of open-textured standards: a morally significant connection; the ability to make an appreciable contribution at modest cost; and a substantial human rights threat. Paraphrasing what Moore (2009: 105) says of the “substantial factor" test for causation, responsibility is a matter of degree and the break 
point between no responsibility and responsibility is often arbitrary. The job of a responsibility framework is to set an appropriately vague line below which one's connection to the rights-holder or violator, one's leverage over relevant others, the cost of exercising leverage, and the threat to human rights will be ignored for purposes of assessing responsibility. As an aside, impact-based responsibility is also graduated, since culpability, causation and non-causal contributions are also matters of degree (Moore 2009: 72, 300, 319-320); but this issue is beyond the scope of my argument.

Not only is there graduation within leverage-based responsibility, there is also graduation between leverage-based and impact-based responsibility. All else being equal, a company bears greater responsibility for human rights harms it has caused than those to which it has contributed causally or non-causally (e.g. by omission or risk imposition); and more for problems to which it has contributed than for those to which it has not, but could help solve. The SRSG recognized this when he wrote that the steps a company takes to address the human rights impacts of its own operations may differ from those regarding its relationships with other social actors, and that its actions regarding the human rights impact of a subsidiary may differ from those in response to impacts of suppliers several layers removed (United Nations 2008a: 8). These distinctions are reflected in the Guiding Principles. Responsibility requires different action depending on whether the company causes or may cause human rights impacts, contributes or may contribute to human rights impacts, or does not contribute to impacts but such impacts are nevertheless directly linked to it via its business relationships. In the first situation, the company's responsibility is stringent: to take the necessary steps to stop or prevent the impact. In the second, it is relaxed somewhat: to take the necessary steps to stop or prevent its contribution and use its leverage to mitigate any remaining impact to the greatest extent possible. In the third, its responsibility is relaxed even farther: it should exercise its leverage, if it has any; seek ways to increase its leverage, if it has none; and if it can do neither, it should consider ending the relationship, taking into account the importance of the relationship to company, the severity of the human rights impacts of the relationship, and the potential human rights impacts of ending it (United Nations 2011b: 18-19). This differentiation reflects the realization that when responsibility is imposed in the absence of contribution to a given state of affairs, it is not appropriate to 
demand that a company remedy the state of affairs, but it is appropriate to demand that it make reasonable efforts to influence those over whom it has some leverage (for example, by making representations to local officials or home country diplomats) (Sorell 2004: 132).

(g) Leverage-based responsibility is context-specific

Although corporate human rights obligations are defined in terms of universal human rights to which all individuals are equally entitled, their concrete content must be determined in relation to a range of contextual factors including the responsible actor's social functions, relationships, impacts, capabilities and environment (Cragg 2010: 272, 289-296). So although the Guiding Principles insist that the responsibility to respect human rights applies fully and equally to all business enterprises regardless of context (United Nations 2011b: 14), the reality is that at any level of concrete detail that has application to actual situations, corporate human rights obligations mean very different things in different contexts (Campbell 2004a: 19).

\section{(h) Leverage-based responsibility is both negative and positive}

The same moral considerations supporting leverage-based responsibility in general also support positive responsibility. The morally significant connection between the company and the rights-holder or rights-infringer and the ability to contribute to improving the rights-holder's situation generate not just a negative responsibility to use leverage to avoid or mitigate the negative impacts of other actors with whom the company has relationships, but also a positive responsibility to use leverage to enhance the positive social or environmental impacts of other actors with whom the company has relationships, even though the company did nothing to cause or contribute to the current state of affairs (Wettstein 2010a). As Wettstein argues against Hsieh (2009), such positive obligations cannot be grounded convincingly in a negative responsibility to do no harm, but entail a positive responsibility to protect human rights (Wettstein 2010c).

The idea that corporations have positive human rights obligations - to protect, promote or fulfill human rights-is increasingly prevalent in business and human rights theory and practice despite the UN Framework's rejection of it. Arnold (2009: 66), for 
example, asserts that corporations "have obligations to both ensure that they do not illegitimately undermine the liberty of any persons, and the additional obligation to help ensure that minimal welfare rights to physical well-being and the development of basic human capacities are met within their sphere of influence”. Cragg (2010: 289) claims that the task of the corporation in areas without well-defined human rights laws "is to mitigate the negative human rights impacts of its activities and enhance positive impacts”. ISO 26000 and the UN Global Compact are two high profile examples from the realm of practice that embrace both negative and positive corporate responsibility.

I do not attempt a systematic defence of positive corporate human rights responsibilities here. My objective is simply to suggest that the moral considerations giving rise to leverage-based responsibility also support positive responsibility. Nor do I claim that my account exhausts the positive responsibilities of corporations, which might alternatively be grounded in multinational corporations' political authority (Kobrin 2009; Wettstein 2010b, 2010c) or in basic Kantian deontological ethics (Arnold 2009: 66); but these possibilities are beyond the scope of my inquiry.

\section{(i) Leverage-based responsibility satisfies the practicality criterion}

Any account of corporate human rights obligations must fulfill the criterion of practicality (Archard 2004; Campbell 2004a, 2004b: 35; Cragg 2010; Griffin 2004). At one level this means that the obligations must be within the capacity of the individual obligation bearer to carry out, an issue I have already addressed. It also means that the obligations must be capable of being embedded, operationalized and enforced in a concrete institutional framework. My account of leverage-based responsibility satisfies this requirement. Human rights in general are already concretely institutionalized via many international and national instruments, agencies and tribunals. They have "a tangible, palpable existence, which gives them a social objectivity in an institutional facticity” (Campbell 2004a: 12). Moreover, the UN Framework and Guiding Principles go some way toward providing a concrete framework to institutionalize the human rights obligations of business, both within individual companies and at a broader institutional level. The Guiding Principles may contemplate a narrower form of leverage-based responsibility than I do, but the concrete processes they propose for assessing human 
rights impacts, exercising or enhancing leverage, ending relationships and providing remedies is, to a first approximation, suitable for the broader responsibility I propose.

Vagueness is the only serious objection that might be raised against my proposal under the heading of practicality. How can companies and other actors implement, monitor and enforce obligations based upon such open-textured standards as “significant," “appreciable," "modest” and "substantial”? One answer is that they do so routinely in other fields, from financial disclosure to environmental impact assessment to risk management to negligence liability. In the field of human rights the open texture of rules and standards is demanded by the moral characteristics of the problems at issue. As I have shown, the criteria giving rise to leverage-based responsibility are continuous rather than dichotomous, and the resulting responsibility is a matter of degree, not an onoff switch. Furthermore, many - perhaps most - of the human rights to which business human rights responsibilities correspond are themselves vague and open-textured. To the extent that this prevents satisfaction of the practicality requirement, this impugns all accounts of business human rights responsibilities, not just mine.

The inherent open-endedness of human rights responsibilities calls for attention to the practical tools and processes by which such responsibilities can be operationalized, a task on which the SRSG's reports, ISO 26000, the UN Global Compact and other initiatives have already made progress. And it calls for recognition that allocation of human rights responsibility, like the identification of a "substantial causal factor" in law, has an irreducible element of arbitrariness that may conflict with what many writers on human rights think (Griffin 2004: 40; Moore 2009: 105). This is as true of the General Principles' “direct link” criterion as it is of my account of leverage-based responsibility. Such arbitrariness can be moderated by operational guidance and institutional practice, but not eliminated.

Leverage-based corporate human rights responsibilities can be and are being embedded in stable, recurring, rule-governed patterns of behaviour, incorporated in corporate management systems, integrated in business operations, monitored, reported and verified (Cragg 2010: 292). It is beyond the scope of this article to provide a detailed description of or prescription for this process of institutionalization; all I do here is to make a prima facie case that it is possible. 
(j) Leverage-based responsibility is appropriate to the social function of business

One of the SRSG's strongest objections to leverage as a basis for allocating responsibility was that it would be inconsistent with the specialized social function of business enterprises. If responsibility arises from leverage, he warned, “a large and profitable company operating in a small and poor country could soon find itself called upon to perform ever-expanding social and even governance functions - lacking democratic legitimacy, diminishing the State’s incentive to build sustainable capacity and undermining the company’s own economic role and possibly its commercial viability” (United Nations 2010: 14). Corporations are "specialized economic organs, not democratic public interest institutions" and as such, "their responsibilities cannot and should not simply mirror the duties of States” (United Nations 2008b: 15; see also Arnold 2010: 374; Cragg 2010: 287).

This might have been a valid complaint against the Draft UN Norms and some of the more grandiose applications of the SOI approach in which corporate spheres of influence and activity provided the only distinction between business and governmental duties, but it does not apply to my proposal for leverage-based responsibility. My requirement of a context-specific, morally significant connection between the company and the rights-holder or perpetrator of human rights harm, like the Guiding Principles’ “direct link" criterion, limits the scope of responsibility and prevents corporations from being called upon, or taking it upon themselves, to become surrogate governments for entire communities or regions. Business enterprises exist primarily to pursue private interests, generating wealth by satisfying demands for goods and services. By restricting their human rights responsibilities to cases where they have a special relationship with the perpetrator or rights-claimant, or where the human rights risk situation is relevant to their activities, products or services, my approach ensures that their responsibility flows from their social role as business enterprises, not simply from their capacity to protect or fulfill human rights.

It is important also to emphasize that leverage-based responsibilities, like business human rights obligations generally, do not arise due to a failure by states to fulfill their own responsibilities. They arise independently, due to moral considerations that make 
businesses obligation-bearers in their own right (Sorell 2004: 141). Furthermore, the state's responsibility to protect human rights is independent of these business responsibilities, and its failure to fulfill its own responsibility is not excused in the least by companies' actions to fulfill theirs. Finally, if the concern is that firms might misuse their leverage to usurp governments and democratic processes, surely this would be inconsistent with social responsibility however defined. Social responsibility implies responsible political involvement (e.g., International Organization for Standardization 2010: clause 6.6.4). There is no question that abuses occur, but there is also no question that companies are capable of exercising their political influence responsibly. A framework for business human rights responsibility should demand that companies do so, not assume that they will not.

As for the SRSG's concern about leverage-based responsibility undermining a company's commercial viability, this is resolved by the criterion of modest cost. Leverage-based responsibility arises only if and to the extent that the cost to the company of exercising leverage is modest relative to the closeness of the connection to the rightsholder or violator, the severity of the human rights threat, and the company's capacity. By definition, therefore, leverage-based responsibility may not force a company out of business. The same is not true, however, of impact-based responsibility. Where a company is causing or contributing to adverse human rights impacts or has the potential to do so, and the price of avoiding or remedying such impacts is to cease doing business, the company must cease doing business - in that place, in that way, or altogether. A corporation has no right to "life" equivalent to that of an individual. It is not a living organism. This fact, plus its lack of a conscious mind or physical body and its potentially immortality, distinguish it in moral terms from individuals. Despite some commentators' claims to the contrary (e.g., Archard 2004: 57-58), a corporation can and should be expected to take actions that would put it out of business, if such actions are required to fulfill its moral obligation not to cause or contribute to adverse human rights impacts. This distinction between impact-and leverage-based responsibility is justified by the greater moral blameworthiness attached to causing or contributing to harm (Moore 2009), and the correspondingly weaker moral imperative to exercise leverage over others to improve a state of affairs not of one’s own making. 


\section{CONCLUSION}

The contemporary debate about corporate leverage emerged mainly in response to the sphere of influence ("SOI”) approach to corporate responsibility. The SOI metaphor is seriously flawed and should be replaced with one more apt such as a "web of relationships”, but the idea of leverage as a determinant of human rights responsibility should be preserved alongside impact-based responsibility. Leverage, understood as a company's ability to contribute to improving a situation by exercising influence over other actors through its relationships, is a consideration in determining who bears corporate human rights obligations. It is not simply a means of discharging responsibility, but can be a source of responsibility where (a) there is a morally significant connection between the company and a rights-holder or rights-violator due either to a relationship to the person or the relevance of the rights-holder's interest to the company's activities, products or services; (b) the company is able, on its own or with others, to make an appreciable contribution to ameliorating the situation by exercising leverage through its relationships; (c) it can do so at modest cost, relative to its resources and the strength of its morally significant connection to the state of affairs; and (d) the threat to the rights-holder's human rights is substantial. In such circumstances companies have a responsibility to exercise their leverage even though they did nothing to contribute to the existing state of affairs. This responsibility is qualified, graduated, contextspecific, practicable, and consistent with the specialized social role of business.

Moreover, it is not merely a negative responsibility to exercise leverage to avoid or reduce harm, but also a positive responsibility to protect, promote and fulfill human rights.

The Guiding Principles go part of the way toward recognizing leverage-based responsibility, but they restrict it too narrowly and fail to articulate the meaning of the “direct link” between adverse impacts and the company's activities, products or services. This article is an effort to put leverage-based responsibility on firmer normative ground and to elaborate its characteristics, including the nature of the required link. Ultimately, as I have tried to show, while the distinction between impact and leverage is morally 
significant, it is the strength of the connections constituted by a company's web of activities and relationships that does most of the moral work in setting the scope of corporate human rights responsibilities.

\section{Notes}

I would like to thank Denis Arnold, Wes Cragg, Peter Muchlinski, Fabrizio Cafaggi, Michel Doucin, Olivier Dubigeon, Alan Fine, Adam Greene, Adrian Henriques, John Ruggie and his staff, Kernaghan Webb, Florian Wettstein, participants in a CBERN Symposium on Business and Human Rights at York University, participants in a graduate seminar on Transnational Private Regulation at the European University Institute, and three anonymous reviewers for valuable feedback on earlier versions, as well as the Social Sciences and Humanities Research Council of Canada and the Robert Schuman Centre for Advanced Studies for research support.

\section{References}

Archard, D. 2004. "Welfare Rights as Human Rights and the Duties of Organisations." In Human Rights and the Moral Responsibilities of Corporate and Public Sector Organisations, eds. T. Campbell and S. Miller. Dordrecht, Netherlands: Kluwer Academic Publishers, 45-59.

Arnold, D. G. 2009. "The Human Rights Obligations of Multinational Corporations." In Normative Theory and Business Ethics, ed. J. D. Smith. Lanham, Maryland: Rowman \& Littlefield, 61-71.

Arnold, D. G. 2010. "Transnational Corporations and the Duty to Respect Basic Human Rights." Business Ethics Quarterly 20(3):371-399.

Banerjee, S., N. Bowie and C. Pavone. 2006. "An Ethical Analysis of the Trust Relationship." In Handbook of Trust Research, eds. R. Bachmann and A. Zaheer. Cheltenham, U.K.: Edward Elgar.

Beckmann, M. and I. Pies. 2008. "Ordo-Responsibility: Conceptual Reflections towards a Semantic Innovation." In Corporate Citizenship, Contractarianism and Ethical Theory: On Philosophical Foundations of Business Ethics, eds. J. Conill, C. Luetge and T. Schönwälder-Kuntze. Farnham, UK and Burlington, VT: Ashgate, 87-115. Bomann-Larsen, L. 2004. "Reconstructing the Principle of Double Effect: Towards Fixing the Goalposts of Corporate Responsibility." In Responsibility in World Business: Managing Harmful Side-Effects of Corporate Activity, eds. L. Bomann-Larsen and O. Wiggen. Tokyo: United Nations University Press, 82-98.

Business Leaders Initiative on Human Rights, United Nations Global Compact Office and Office of the United Nations High Commissioner for Human Rights. (no date). "A 
Guide for Integrating Human Rights into Business Management (2nd ed.): Global Business Case: Supporting Tools ". Available online at http://www.integratinghumanrights.org/global_business_case_sphere_of_influence. Campbell, T. 2004a. "Moral Dimensions of Human Rights." In Human Rights and the Moral Responsibilities of Corporate and Public Sector Organisations, eds. T. Campbell and S. Miller. Dordrecht: Kluwer Academic Publishers, 11-30.

Campbell, T. 2004b. Rights: A Critical Introduction. London: Routledge. Cragg, W. 2004. "Human Rights, Globalisation and the Modern Shareholder Owned Corporation." In Human Rights and the Moral Responsibilities of Corporate and Public Sector Organisations, eds. T. Campbell and S. Miller. Dordrecht, Netherlands: Kluwer Academic Publishers, 105-127.

Cragg, W. 2010. "Business and Human Rights: A Principle and Value-Based Analysis." In The Oxford Handbook of Business Ethics, eds. G. G. Brenkert and T. L. Beauchamp. New York: Oxford University Press, 267-304.

de Schutter, O. 2006. "The Challenge of Imposing Human Rights Norms on Corporate Actors." In Transnational Corporations and Human Rights, ed. O. d. Schutter. Oxford and Portland, Oregon: Hart Publishing, 1-39.

Dunfee, T. 2006. "Do Firms with Unique Competencies for Rescuing Victims of Human Catastrophes have Special Obligations? Corporate Responsibility and the AIDS Catastrophe in Sub-Saharan Africa." Business Ethics Quarterly 16(2):185-210. Gibson, K. 2007. Ethics and Business: An Introduction. Cambridge, UK: Cambridge University Press.

Goodpaster, K. E. 2010. "Corporate Responsibility and its Constituents." In The Oxford Handbook of Business Ethics, eds. G. G. Brenkert and T. L. Beauchamp. New York: Oxford University Press, 126-157.

Griffin, J. 2004. "Human Rights: Whose Duties?" In Human Rights and the Moral Responsibilities of Corporate and Public Sector Organisations, eds. T. Campbell and S. Miller. Dordrecht, Netherlands: Kluwer Academic Publishers, 31-43.

Hart, H. L. A. 1967. "Varieties of Responsibility." Law Quarterly Review 83:346-364. Hart, H. L. A. 2008. Punishment and Responsibility: Essays in the Philosophy of Law. 3rd edition. Oxford: Oxford University Press.

Hart, H. L. A. and T. Honoré. 1985. Causation in the Law. 2nd edition. Oxford: Clarendon Press.

Hsieh, N.-h. 2009. "Does Global Business Have a Responsibility to Promote Just Institutions?" Business Ethics Quarterly 19(2):251-273.

International Organization for Standardization. 2009. Draft International Standard ISO/DIS 26000, Guidance on social responsibility. Geneva: International Organization for Standardization.

International Organization for Standardization. 2010. ISO 26000:2010, Guidance on social responsibility. 1st edition. Geneva: International Organization for Standardization. International Organization for Standardization. n.d. "ISO/WG SR participation." Available online at http://www.iso.org/iso/sr_participation. Kobrin, S. J. 2009. "Private Political Authority and Public Responsibility: Transnational Politics, Transnational Firms and Human Rights." Business Ethics Quarterly 19(3):349374. 
Kutz, C. 2000. Complicity: Ethics and Law for a Collective Age. Cambride, UK: Cambridge University Press.

Moon, J., A. Crane and D. Matten. 2008. "Corporate Power and Responsibility: A Citizenship Perspective." In Corporate Citizenship, Contractarianism and Ethical Theory: On Philosophical Foundations of Business Ethics, eds. J. Conill, C. Luetge and T. Schönwälder-Kuntze. Farnham, UK and Burlington, VT: Ashgate, 9-27.

Moore, M. S. 2009. Causation and Responsibility: An Essay in Law, Morals, and Metaphysics. Oxford: Oxford University Press.

Murphy, C. N. and J. Yates. 2009. The International Organization for Standardization (ISO): Global Governance through Voluntary Consensus. London and New York: Routledge.

Nagel, T. 1986. The View From Nowhere. New York; Oxford: Oxford University Press. O'Neill, O. 1985. Faces of Hunger. London: Allen \& Unwin.

O'Neill, O. 1996. Towards Justice and Virtue. Cambridge, UK: Cambridge University Press.

Palmer, E. 2004. "Real Corporate Responsibility." In International Corporate

Responsibility: Exploring the Issues, eds. J. Hooker and P. Madsen. Pittsburgh, PA: Carnegie Mellon University Press, 69-83.

Pies, I., S. Hielscher and M. Beckmann. 2009. "Moral Commitments and the Societal Role of Business: An Ordonomic Approach to Corporate Citizenship." Business Ethics Quarterly 19(3):372-401.

Ruggie, J. G. 2007. "Business and Human Rights: The Evolving International Agenda." American Journal of International Law 101:819-840.

Ruggie, J. G. 2008. "Protect, Respect and Remedy: A Framework for Business and Human Rights." Innovations(Spring):189-212.

Santoro, M. A. 2010. "Post-Westphalia and Its Discontents: Business, Globalization, and Human Rights in Political and Moral Perspective." Business Ethics Quarterly 20(2):285297.

Scherer, A. G. and G. Palazzo. 2007. "Toward a Political Conception of Corporate Responsibility: Business and Society Seen from a Habermasian Perspective." Academy of Management Review 32:1096-1120.

Scherer, A. G., G. Palazzo and D. Matten. 2009. "Introduction to the Special Issue: Globalization as a Challenge for Business Responsibilities." Business Ethics Quarterly 19(3):327-347.

Schmidtz, D. 2000. "The Moral and Legal Limits of Samaritan Duties." Law and Philosophy 19(6):683-705.

Sorell, T. 2004. "Business and Human Rights." In Human Rights and the Moral Responsibilities of Corporate and Public Sector Organisations, eds. T. Campbell and S. Miller. Dordrecht, Netherlands: Kluwer Academic Publishers, 129-143.

Soule, E., M. Hedahl and J. Dienhart. 2009. "Principles of Managerial Moral Responsibility." Business Ethics Quarterly 19(4):529-552.

Ulrich, P. 2008. Integrative Economic Ethics: Foundations of a Civilized Market Economy Cambridge, UK: Cambridge University Press.

United Nations. C. o. H. Rights. S.-C. o. t. P. a. P. o. H. Rights. 2003. Norms on the responsibilities of transnational corporations and other business enterprises with regard to human rights (23 August), UN Doc. E/CN.4/Sub.2/2003/12/Rev.2. 
United Nations. O. o. t. H. C. f. H. Rights. 2005a. Report of the United Nations High Commissioner on Human Rights on the responsibilities of transnational corporations and related business enterprises with regard to human rights (15 February), UN Doc. E/CN.4/2005/91.

United Nations. C. o. H. Rights. 2005b. Resolution 2005/69, Human rights and transnational corporations and other business enterprises (15 April), UN Doc. E/CN.4/2005/L.87.

United Nations. S. R. o. t. S. G. o. B. a. H. R. J. Ruggie). 2006. Interim report of the Special Representative of the Secretary-General on the issue of human rights and transnational corporations and other business enterprises (22 February), UN Doc. E/CN.4/2006/97.

United Nations. S. R. o. t. S. G. o. B. a. H. R. J. Ruggie). 2007. Business and human rights: mapping international standards of responsibility and accountability for corporate acts. Report of the Special Representative of the Secretary-General on the issue of human rights and transnational corporations and other business enterprises, John Ruggie (19 February), UN Doc. A/HRC/4/35.

United Nations. S. R. o. t. S. G. o. B. a. H. R. J. Ruggie). 2008a. Clarifying the Concepts of "Sphere of Influence" and "Complicity". Report of the Special Representative of the Secretary-General on the Issue of Human Rights and Transnational Corporations and other Business Enterprises, John Ruggie (15 May), UN Doc. A/HRC/8/16. United Nations. S. R. o. t. S. G. o. B. a. H. R. J. Ruggie). 2008b. Protect, Respect and Remedy: A Framework for Business and Human Rights. Report of the Special Representative of the Secretary-General on the issue of human rights and transnational corporations and other business enterprises, John Ruggie (7 April), A/HRC/8/5. United Nations. H. R. Council. 2008c. Resolution 8/7, Mandate of the Special Representative of the Secretary-General on the issue of human rights and transnational corporations and other business enterprises (18 June), (28th meeting; adopted without a vote). United Nations. S. R. o. t. S. G. o. B. a. H. R. J. Ruggie). 2009. Note on ISO 26000 Guidance Draft Document (November 2010),

United Nations. S. R. o. t. S. G. o. B. a. H. R. J. Ruggie). 2010. Business and Human Rights: Further steps toward the operationalization of the "protect, respect and remedy" framework. Report of the Special Representative of the Secretary-General on the issue of human rights and transnational corporations and other business enterprises, John Ruggie (9 April), UN Doc. A/HRC/14/27.

United Nations. 2011a. "Council establishes Working Group on human rights and transnational corporations and other business enterprises (media release)." Geneva: United Nations Human Rights Council.

United Nations. S. R. o. t. S. G. o. B. a. H. R. J. Ruggie). 2011b. Guiding Principles on Business and Human Rights: Implementing the United Nations "Protect, Respect and Remedy” Framework. Report of the Special Representative of the Secretary-General on the issue of human rights and transnational corporations and other business enterprises, John Ruggie (advance edited version) (21 March), UN Doc. A/HRC/17/31. United Nations Global Compact Office. (no date). "The Ten Principles." Available online at http://www.unglobalcompact.org/AboutTheGC/TheTenPrinciples/index.html. 
Voiculescu, A. 2007. "Changing Paradigms of Corporate Criminal Responsibility: Lessons for Corporate Social Responsibility." In The New Corporate Accountability: Corporate Social Responsibility and the Law, eds. D. McBarnet, A. Voiculescu and T. Campbell. Cambridge, UK: Cambridge University Press, 399-430.

Weissbrodt, D. 2008. "International Standard-Setting on the Human Rights Responsibilities of Businesses." Berkeley Journal of International Law 26:373-391. Weissbrodt, D. and M. Kruger. 2003. "Norms on the Responsibilities of Transnational Corporations and Other Business Enterprises with Regard to Human Rights." American Journal of International Law 97(4):901-922.

Wettstein, F. 2010a. "Breaking the Silence: When Corporations Must Speak Out For Human Rights." In CBERN Symposium on Business and Human Rights. Toronto. Wettstein, F. 2010b. "The Duty to Protect: Corporate Complicity, Political Responsibility, and Human Rights Advocacy." Journal of Business Ethics 96(1):33-47. Wettstein, F. 2010c. "For Better or For Worse: Corporate Responsibility Beyond "Do No Harm"." Business Ethics Quarterly 20(2):275-283.

Wiggen, O. and L. Bomann-Larsen. 2004. "Addressing Side-Effect Harm in the Business Context: Conceptual and Practical Challenges." In Responsibility in World Business: Managing Harmful Side-Effects of Corporate Activity, eds. L. Bomann-Larsen and O. Wiggen. Tokyo: United Nations University Press, 3-13.

Windsor, D. 2001. "Corporate Citizenship: Evolution and Interpretation." In Perspectives on Corporate Citizenship, eds. J. Andriof and M. McIntosh. Sheffield, UK: Greenleaf, 39-52.

Wood, S. 2011a. "Four Varieties of Social Responsibility: Making Sense of the "Sphere of Influence" and "Leverage” Debate Via the Case of ISO 26000." In Osgoode Comparative Research in Law \& Political Economy Research Paper Series. Toronto: Osgoode Hall Law School, 21.

Wood, S. 2011b. "'Sphere of Influence" in ISO 26000." In Understanding ISO 26000: A Practical Approach to Social Responsibility ed. A. Henriques. London: British Standards Institution, (forthcoming).

Young, I. M. 2004. "Responsibility and Global Labor Justice." Journal of Political Philosophy 12(4):365-388. 